\title{
AC 2010-325: DEVELOPMENT AND EVALUATION OF A DECISION MODEL FOR APPROVAL OF CIVIL ENGINEERING INDEPENDENT STUDY PROJECTS
}

\section{Brock Barry, United States Military Academy}

Dr. Brock E. Barry is an Assistant Professor in the Department of Civil \& Mechanical Engineering at the U.S. Military Academy at West Point. Dr. Barry is a licensed professional engineer in multiple states and accumulated 10-years of industry experience prior to entering academics.

\section{Jeffrey Braun, United States Military Academy}

MAJ Jeff Braun is an Instructor in the Department of Civil \& Mechanical Engineering at the U.S. Military Academy at West Point. MAJ Braun is a licensed professional engineer in California and has served as an Engineer Officer in the U.S. Army for over 10 years.

\section{Mark DeRocchi, United States Military Academy}

Major Mark DeRocchi is an Instructor in the Department of Civil \& Mechanical Engineering at the U.S. Military Academy at West Point. He has been an Officer in the US Army Corps of Engineers for 12 years including assignments in Alaska, Hawaii, Missouri, Tennessee, Korea, Japan, Kuwait, and Iraq. 


\title{
Development and Evaluation of a Decision Model for Approval of Civil Engineering Independent Study Projects
}

\begin{abstract}
Like most departments of engineering the Department of Civil \& Mechanical Engineering at the United States Military Academy continuously strives to balance various factors when evaluating course offerings and instructor workloads. Independent study projects represent a significant strain on that balance. The Department of Civil \& Mechanical Engineering is currently in the midst of a considerable curriculum adjustment. One of the many benefits of this change is the move towards an increase in the number of Firstie (Senior) Year engineering electives. In an effort to reduce the demands on the faculty advising independent study projects and to encourage increased Cadet enrollment in engineering electives, the Department has chosen to reduce the number of independent study project offerings. It is the desire of the Department to develop and evaluate a decision model for judging prospective independent study projects. The focus of this document is the process of exploring, developing, and evaluating such a decision model.

The decision modeling literature has been reviewed and the use of a Multi-Criteria Decision approach has been selected. The Multi-Criteria Decision Model, more commonly known as a weighted decision matrix, gives the user a full spectrum of options to evaluate a decision. A decision matrix can accommodate changes in the input parameters over time. In addition, the engineering education literature has been reviewed and notably little evidence has been found of application of decision models for "go/no go" type evaluations of independent study projects. This study holds the generative promise of adding to the literature in this arena.

This document includes a review of the applicable educational and decision modeling literature. Further, the various stakeholders and parameters utilized in the development of our MultiCriteria Decision Model are detailed herein. The process of evaluating the Model relative to multiple years of Department records of prior authorized independent study projects is described and associated statistics are reported. The results of this decision modeling development process are likely to be of interest to all engineering educators charged with the process of making curriculum decisions and particularly those decisions in which the influence of multiple stakeholders and parameters must be considered.
\end{abstract}

\section{Background}

Although the exact date when independent study projects were introduced to the civil engineering curriculum at the United States Military Academy is unclear, various records ${ }^{1,2,3}$ indicate that the practice has been in place for more than 35 years. In general, the nature of these independent study projects has been largely within one of three different classifications: servicebased, competition-based, or research-based. The number of independent study projects offered and executed over the years has fluctuated as a result of such factors as Department enrollment, available faculty, and interests of the Cadets. Typically, there has never been a lack of "good ideas" brought forth for consideration and conversion into a formal independent study project. However, the process by which these ideas were evaluated and ultimately either rejected, tabled, 
or authorized has varied and has largely been at the discretion of the independent study course director who oversees the conduct of all such projects.

The Department of Civil \& Mechanical Engineering at the United States Military Academy continuously strives to balance the influence and concerns of various stakeholders (e.g. current Cadets, alumni, faculty, etc.). This is particularly true when evaluating future course offerings and instructor workloads. Independent study projects have historically represented a significant strain on that balance. The Department of Civil \& Mechanical Engineering (D-C\&ME) is currently implementing several changes in the program's curriculum. These changes include a move towards an increase in the number of the senior year engineering electives offered. In an effort to reduce the demands on the faculty advising independent study projects and to encourage increased Cadet enrollment in engineering electives, the D-C\&ME has chosen to reduce the number of independent study project offerings. The D-C\&ME opted to evaluate its current methods for authorizing or rejecting potential projects and then choose to develop a decision model for judging perspective independent study projects. The research question utilized in this study was generated as a result of that process; simply "can a successful decision model be developed and evaluated that considers the applicable parameters and stakeholders and allows us to authorize appropriate independent study projects?"

\section{Literature Review}

This literature review began with a general survey of publications on the topic of independent studies in the engineering curriculum. Then the decision making model literature was reviewed to provide the reader with appropriate background on the subject relative to its application to the study.

While much has been published on the subject of independent study in the engineering curriculum, an extensive search led to little information on the process of selecting appropriate independent study projects. Rather than utilizing a formal evaluation and decision process, most of the identified resources ${ }^{1,2,3,4,5,6,7,8}$ provided simple justifications for performance of independent study projects. These justifications typically included important considerations which, when summarized, hold the potential to be utilized as selection criteria for such projects. The following table is a summarization of the common considerations noted within several prior independent study publications:

Table 1 - Summarized List of Independent Study Project Considerations

- Does the potential project have a well defined scope?

- Is there a detailed timeline for benchmarks and deliverables (contract)?

- Does the project offer a unique learning experience?

- Is the project challenging, but reasonable for undergraduate level students?

- Will students have some freedom with respect to research methods and approaches to the solution?

- Is there faculty interested in the subject and willing to apply the effort required to make it successful?

- Are the project requirements feasible/manageable given time and resources?

- Is the project perceived as authentic and valuable?

- Will the project result in an artifact (object or report) that will be used subsequently?

- What is the potential for the project to be interesting and/or fun? 
Among the identified literature there was little common overlap. In fact, it could be argued that the summarized list of criteria contains several considerations that are contradictory. At least one resource ${ }^{4}$ identified during our study did recognize the potential contradiction and emphasized the delicate balance between a well-defined scope, including required deliverables, and allowing students some latitude to choose research methods and potential plans of action. In the text "Motivating Project Based Learning", Blumenfeld, et al. ${ }^{4}$ state that students often do not have sufficient knowledge and insight to fully develop a scope and advance a list of requirements for the project. That is, they typically need assistance with identifying the deliverables and possible resources available for the project. Further, Blumenfeld, et al. ${ }^{4}$ describe that students must have the competence to complete a project satisfactorily or they will try to simplify the problem and potentially provide less effort, striving to meet only the minimum requirements. Each of these project characteristics influence the level of interested held by students' in the project and whether or not they will enjoy the experience or simply suffer through a list of requirements. Gehringer ${ }^{5}$, writing on the subject of independent studies, states that wisely chosen projects play a large part in students' development because they typically engage students at a higher level of Bloom's Taxonomy. Clearly, to ensure that our students (and faculty) benefit from performance of an independent study project, due consideration of the applicable criteria is a must.

Faculty members engaged in various roles associated with independent study projects often contribute large amounts of time to make the projects a success and, thus, their initial level of interest is an important consideration. While students stand to benefit from an interested and motivated member of the faculty involved with an independent study project, the literature was mixed relative to the potential for tangible benefits to the individual faculty member. Gehringer ${ }^{5}$ discussed how independent study projects can help faculty meet tenure and promotion requirements, while an article by Sanford-Bernhardt and Roth ${ }^{8}$ described how most projects at Lafayette College did not result in products that assisted with faculty development. This may be the result of the disparity between the level of knowledge and skill of most undergraduate students and forward-thinking research required of faculty for promotion and tenure at many academic institutions.

Iteration and optimization have long been the hallmark of a successful engineering process. It is in the nature of engineering to not only find a solution, but to find the best solution that satisfies the required parameters. However, optimization is not a characteristic solely unique to engineering. Thus, it comes as no surprise that in the last 40 years a voluminous amount of literature has been generated dedicated to the subject of optimization through the application of decision modeling. Multi-Criteria Decision Making (MCDM) is a fast growing and well studied form of decision making modeling. From selecting the right spot for maple sugar production to increasing Wall Street profit margins, MCDM can be and has been used for a wide variety of applications ${ }^{9}$.

There are a diverse number of MCDM models to choose from. However, all MCDM models have common aspects. Use of a simple Decision Matrix (a form of MCDM) does not require extensive knowledge of the subject. However, to select the right MCDM for a certain application, it is important to understand where all the models come from and how each is 
different ${ }^{10}$. Vast literature is available to aid in the selection and application of the correct MCDM for particular conditions $9,10,11,12,13$. One of the first steps in this process is consideration of applicable variables. Further, how will each variable be screened and prioritized? Are their hierarchical alternatives that when selected eliminate other alternatives? What are the attributes of each alternative to be reviewed? What if two different criteria suggest different things for the same alternative? Will there be incommensurable units or values of different scale? How will the criteria be weighted? All these questions help determine the level of decision making and the best type of MCDM model to use ${ }^{12}$. One might even be inclined to make a decision matrix to select which MCDM to use. However, once the above questions are answered the proper MCDM can be selected.

When selecting a MCDM, understanding the math and permutations of options help to narrow the user's alternatives. The first decision is based on unlimited (continuous) or finite (discrete) options (data sets) for the model. Commonly Multi-Objective Decision Making (MODM) is used for the former while Multi-Attribute Decision Making (MADM) is used for the latter. By far the most common is MADM, if for no other reason than for simplification of the mathematics. Under the assumption of MADM, there are four main categories based on the type of solutions that present themselves or the math used to generate the solutions ${ }^{11}$. These are: Hierarchical Models (use of pairwise comparisons for data sets), Deterministic Models (a single decision maker), Stochastic Models (non-deterministic with random elements for data sets), and Fuzzy Models (approximating multi-valued logic for data sets). The most common is Deterministic Models because most users are dealing with options that are mathematically straightforward or there are pre-known instructions that mandate certain dimensions. In the subset of MADM and Deterministic Models there are three subcategories: Conjunctive Method (set A is better if...), Elimination by Aspect (data XYZ is most important), and Cardinal Values (criteria hold a numeric value). Those in the business of rank ordering or "determining an order of merit" will almost always find themselves using Cardinal Values so they can determine the specific magnitude of each option with regards to all other options. As such, this is the same reasoning used during the study detailed herein.

In the subset of the Cardinal Values, by far the most common MCDM, is the Weighted Sum Model (WSM). The WSM is extremely popular partly because of pure simplicity, but also because the end product is a rank ordered list of options or the elusive "order of merit". However, the WSM is also the most misused MCDM. There are numerous situations that should, by definition, use the Weighted Product Model (WPM) for mixed units, the Elimination and Choice Translating Reality (ELECTRE) for pairwise comparisons, or Technique for Order Preference by Similarity to Ideal Solution (TOPIS) for graphical plotting of worse to ideal. Whatever the type of model, it must be applied correctly to provide the user with a powerful guide to help select the best choice ${ }^{12}$.

\section{Decision Model Development}

Presented within this section of the document is the process utilized in selecting an appropriate decision making model and the development of that model in relation to the authors' independent study criteria. Each criteria is also identified and discussed herein. 
As noted previously, the MCDM field of study is extremely broad. Thus, in preparation for selecting the proper MCDM model, the authors found it helpful to create a flow chart to ensure selection of the appropriate type of model (see Figure 1).

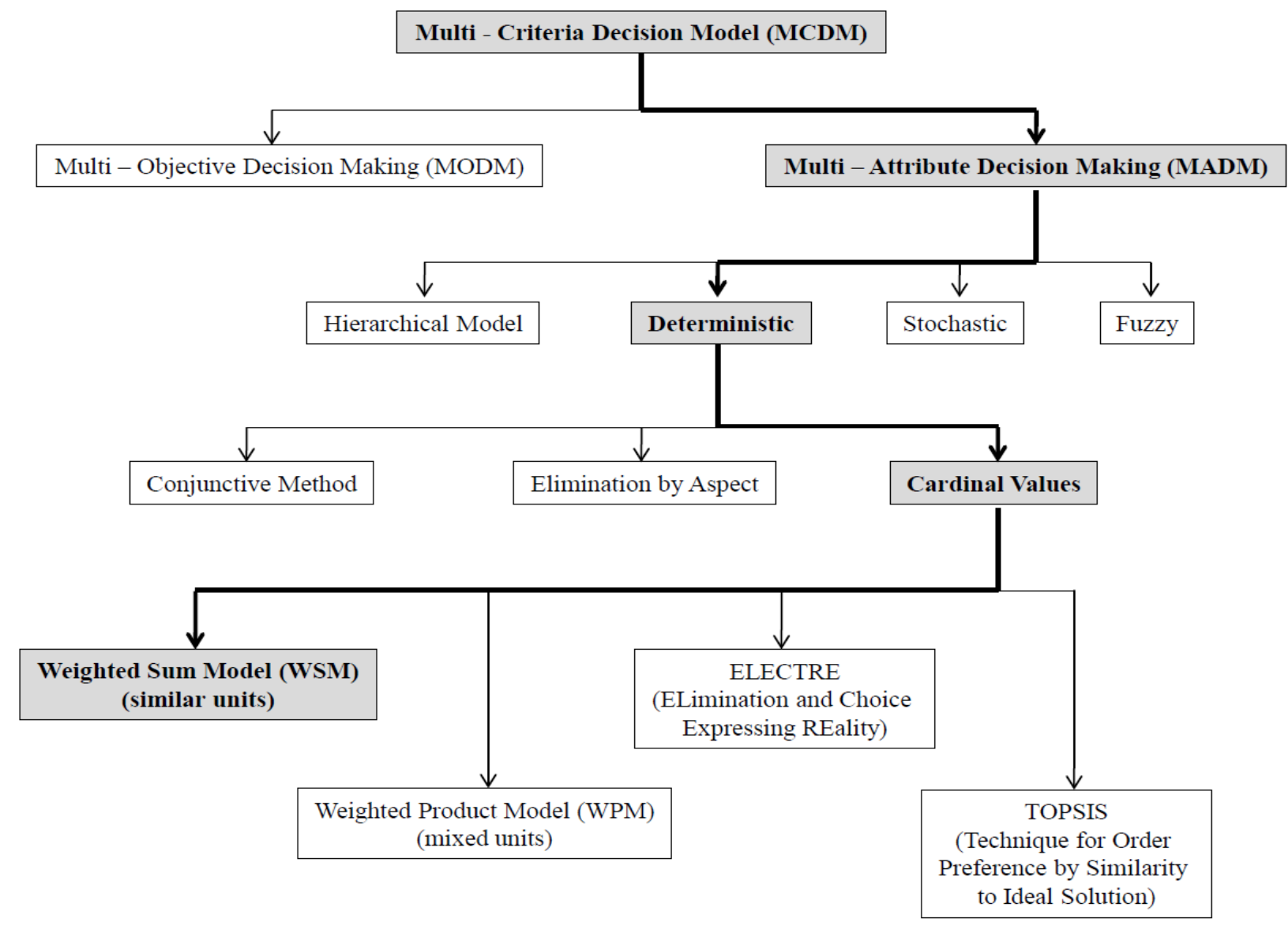

Figure 1 - Multi-Criteria Decision Model Flow Chart 1

Given the desired end state of this study to provide a general order of merit for potential independent study projects and the knowledge of a finite number of data combinations, as well as the ability to assign a value to those combinations, the decision model literature suggests that the appropriate model for application to this study was either a Weighted Sum Model (WSM) or a Weighted Product Model (WPM). Both of these approaches are subsets of Cardinal Values and Deterministic Models. However, in relation to this study a dilemma is created when considering the combination of both mixed units and a desire to generate a hierarchal rating. The most common approach to addressing this dilemma is to re-assign criteria with a scaled value in lieu of actual units.

To select the criteria that would serve to analyze each course of action the authors utilized stakeholders identified in the D-C\&ME's 10-year Strategic Plan ${ }^{14}$. The list of stakeholders are reviewed and agreed upon by the senior leadership of the D-C\&ME faculty on an annual basis during a strategic planning workshop. While the list does not change often, it does serve to tie the independent study decision model to the Department's goals. 
Initially it seemed natural to have a two-part decision matrix. The first set of criteria was envisioned as hierarchy based and serving as a simple GO/NO-GO decision. Any proposed independent study project that failed to meet the first set of criteria would be automatically negated. However, upon further review, this logic proved unfounded as there were past academic years that always had exceptions to these criteria that ended up being fantastic projects. Further, some of the initial criteria were noted to have little or no influence on the hierarchal rating due to commonality in the scaled criteria value. This resulted in a modification of the list of criteria to reflect more than simply the D-C\&ME stakeholders.

Finally, there were some aspects of this criteria list that were either redundant, didn't stand out as truly independent, or were not feasible to rank and scale. Consequently, the modified criteria list was further paired down by merging some items, deleting others, and finally updating the remaining items. See Table 2 for the final criteria list. This final list of criteria is reflected along the top of the model as presented in Figure 2.

Table 2 - D-C\&ME Independent Study Project Decision Model Criteria
- Benefit to West Point
- Benefit to the Department
- Benefit to the US Army
- Relationship with Professional Societies
- Relationship with Project Sponsors
- Strategic Communication
- Project Costs
- Cadet Interest and Development Potential
- Faculty Interest and Development Potential

By providing a "scale" for each of the criteria (for example 1-10), the model's user can then negate the predicament of mixed units and still use the WSM to generate an order of merit. Definition was then provided by the authors for each scale value (e.g. with respect to "Faculty" what does a "1" verse a "10" mean?). The scale values are located at the bottom of each column of criteria on Figure 2. The next step was to assign a weighting value to each of the criteria. That is, each criteria was considered and weighted in relation to each other. The assigned weight for each criteria is located immediately below the column (criteria) heading in Figure 2. After assigning weights, a consistency check was performed to ensure that the weighting was mathematically consistent. A consistency check is a common mathematical tool to ensure nonbiased weighting. The consistency check provides a structured approach to review the weighting values, which are often difficult to subjectively determine, by using an Analytic Hierarchy Process (AHP) to review. Figure 3 shows the required AHP steps outlined by Ragsdale in his book Spreadsheet Modeling \& Decision Analysis: Pairwise Comparison, Normalizing the Comparisons, and Consistency Check $^{15}$. A perfectly consistent pairwise comparison would yield an average consistency that is equal to the number of criteria which in turn would result in a consistency ratio of 0 . If the consistency ratio is $\leq 0.10$ the pairwise comparison is considered satisfactory. As seen in Figure 3, the consistency ratio for the weighted criteria was 0.064 , significantly less than 0.10 . 


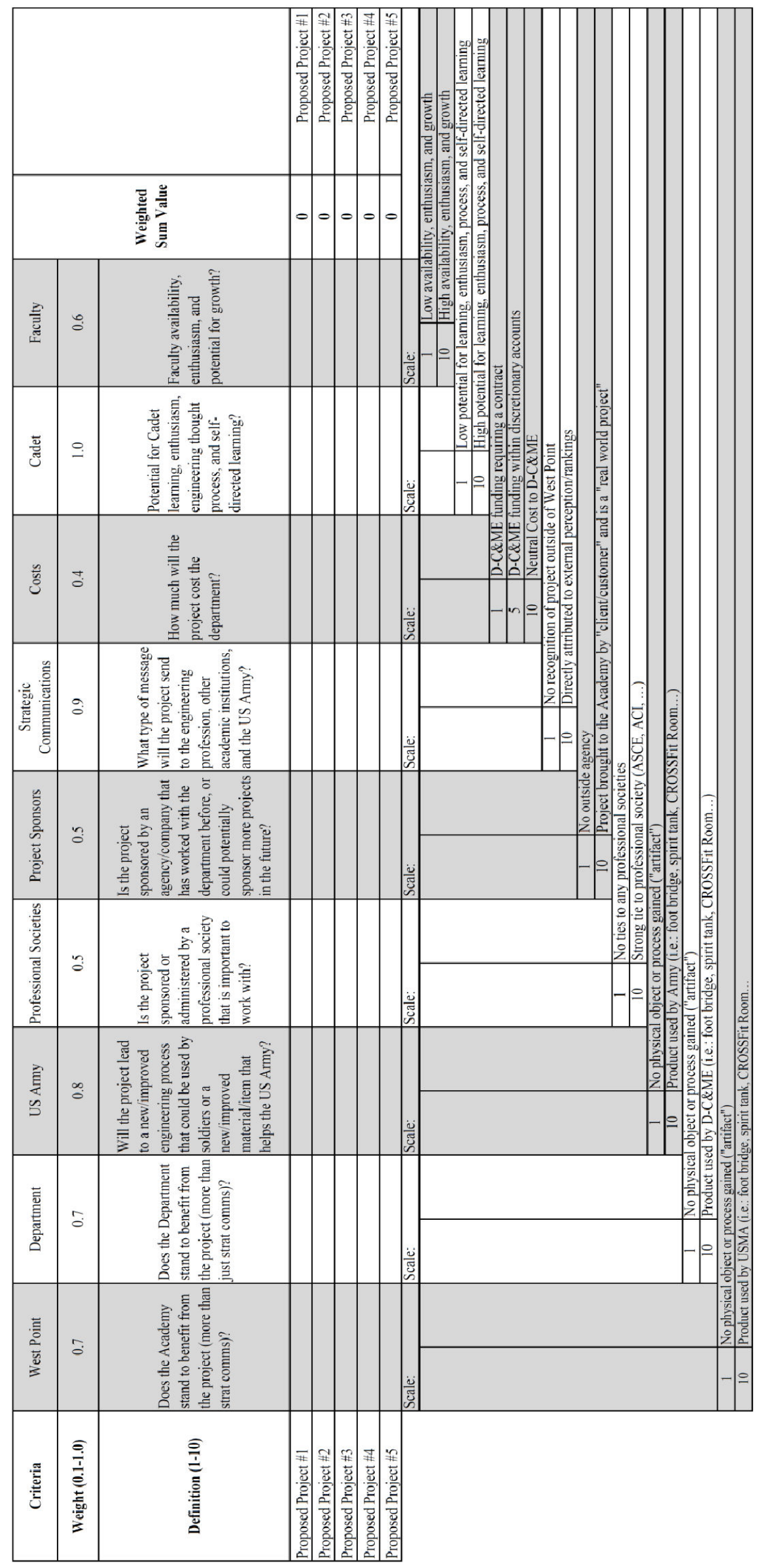

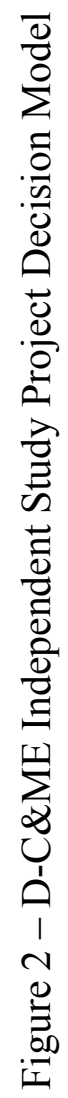


As noted previously, the selection of model criteria was an iterative process. The following paragraphs provide a brief description of each criterion and the methods for assigning values as a part of our model. It should be noted that the order of the individual criteria presented in this document and listed on the model (see Figure 2) does not influence the model output.

The first selection criterion considered in our model was whether or not the United States Military Academy (West Point) would benefit from the project in any form other than strategic communications. This could include physical products or a new/improved process for an engineering problem at the Academy. A scale value of 1 was assigned to projects that have no foreseen benefit to West Point, while a value of 10 was assigned to projects leading to a physical artifact or process that improves conditions at the Academy. Examples of projects earning a higher score would be the design and construction of a footbridge and improved techniques for pothole repair.

The next criterion considered in our model was whether or not the D-C\&ME would benefit from the project in any form other than strategic communications. This refers to physical products or new/improved processes that help the D-C\&ME. While in principle this criterion may appear very similar to the previous criterion, the end user was considered sufficiently different to justify separate criteria. Values were assigned to projects in an identical manner as the prior criterion. A value of 1 was assigned to projects that have no foreseeable benefit and a value of 10 was assigned to projects leading to a physical artifact or process that helps the D-C\&ME. Examples of projects considered beneficial would be those involving competitions (i.e. steel bridge, concrete canoe, timber bridge) since they potentially result in physical models which instructors could use as teaching aids during future lessons.

The benefit to the US Army criterion is similar to the first two criteria, but it is applied to the Army as a whole. Values were assigned based on whether or not the project benefits the US Army. Again, this benefit could be physical or a new/improved process. The values are assigned the same way; 1 means no benefit and a value of 10 is assigned to projects that lead to potential physical objects or processes that could improve Army operations. Examples of projects earning high values for this criterion include improved designs for blast resistant concrete and expedient pothole repair techniques.

Another criterion included in our decision model was whether or not the project was affiliated with a professional society. Working with professional societies increases opportunities for strategic communications and allows for interaction between our program and other high quality engineering programs around the country. A project with no ties to a professional society was assigned a value of 1 while projects tied to professional societies earned a 10. The competition projects such as concrete canoe, steel bridge, and timber bridge are examples of projects that earned high values for this criterion because of their direct relationship with high profile professional societies.

Whether or not the project was sponsored by an outside agency was another factor considered an important part of the decision making model. Project sponsors are desired as they often assist with strategic communications in addition to the potential for sponsoring additional projects in the future. While this criterion is related to costs, it is not synonymous as it incorporates more 
than just the short term budgetary requirements. Cost of a potential independent study project is considered under a subsequent criterion. Projects initiated by our academic department that are not tied to any outside agencies received a value of 1 for this criterion. Higher values, up to 10, were assigned for projects brought to the department by reputable outside agencies that could bring additional projects to us in the future. Some project sponsors that have worked with DC\&ME in the past include the National Parks Service and the West Point Directorate of Public Works.

Strategic communications are very important to any academic program as they can play a direct role in several national ranking systems. For purposes of this model and study, strategic communications was defined as positive graphics (including photographs) and supporting text that casts the Department and West Point in a favorable light from the standpoint of the various stakeholders identified in the Department Strategic Plan. D-C\&ME views our independent study projects as a form of representation and "branding" of the Department and West Point to other schools, the engineering profession, and the Army. Smaller and low impact projects were valued low within the model. High valued projects included technically advanced research, widely applicable engineering solutions, or high-visibility projects.

Project costs are another factor considered when evaluating independent study projects. While it is considered the least important factor in our model (lowest weighting), it was still perceived to be a necessary criterion to evaluate the potential costs associated with the project. The costs considered include hardware and materials, testing, travel, publishing, and the use of external resources. A scale value of 1 was assigned to projects requiring a contract for the Department to get funding and a scale value of 5 for projects the Department can fund within discretionary accounts. Fully funded projects, not requiring any money from the Department's budget, were assigned a scale value of 10 .

One of the most important criteria in our model (as suggested from the weighting) was the anticipated level of Cadet interest and cognitive development related to the project. Specifically, would the project involve challenging and unique problems that Cadets would enjoy? As mentioned in our review of the applicable literature, students must have the competence to complete the project satisfactorily or they will try to simplify the problem and potentially provide less effort, striving to meet only the minimum requirements. They can be motivated by the type of project, the scope of the project, or by the freedom they have to influence the project goals and methods to meet the requirements. This is also where the model evaluates whether the project is in-line with course objectives ${ }^{16}$, which are developed in relation to ABET accreditation standards. This criterion is fairly subjective, so it was important to strive for consistency when comparing various projects. Low values were assigned to projects that have a low potential for Cadet development, enthusiasm, and self-directed learning while high values were given to projects with greater potential in those areas.

The final criterion in the model is faculty interest and development. Specifically, are faculty members excited about the project and will those involved experience personal and professional growth through their involvement with the independent study? Faculty development is defined as occurring directly through gaining knowledge and experience as an advisor to the project, or indirectly for the non-advising faculty through a report or presentation. Independent study 
projects are typically more advanced than standard course projects, and could provide an opportunity for faculty members and their peers to participate in new engineering research or learn new processes. It is possible that the project results could assist faculty advisors with promotion or gaining tenure as well. As with Cadet interest and development, this criterion is subjective. Projects with little potential to capture faculty interest or help with their development were assigned a value of 1 . Higher values were given to projects that were exciting and held potential for professional publication or presentation.

\section{Decision Model Testing}

In an effort to evaluate our MCDM's strength as a predictor of appropriate independent study projects to authorize, the authors applied the model to several independent study projects completed or on-going currently. Specifically, the model was used to evaluate 11 independent study projects that were authorized and completed during the 2008-2009 academic year, as well as 8 independent study projects authorized and on-going during the 2009-2010 academic year. All independent study projects within the D-C\&ME are executed under the requirements of a contract prepared collectively at the start of the academic year by the Cadets, faculty member(s) acting as the project advisor(s), and the course director responsible for oversight of all independent study projects. The authors utilized only those contracts to evaluate the projects using the model. None of the authors were involved with 2008-2009 independent study projects and thus, they had limited prior knowledge of each projects level of success that could have influenced the pre-performance evaluation. One of the three authors who performed the analysis for the 2009-2010 is an advisor for an on-going project, but the second and third authors' analysis was used as the primary model input for that particular project. The D-CME Acting Deputy Department Head, as well as the independent study course director performed a postperformance analysis using the model for the 2008-2009 academic year projects. The postperformance analysis was performed based on knowledge of the complete projects. Numerical values generated by the MCDM for the pre-performance 2008-2009 and 2009-2010 projects, as well as the post-performance 2008-2009 projects are reported in Table 3. The D-CME Acting Deputy Department Head and the independent study course director will use the model to perform the post-performance analysis of the on-going projects at the end of the 2009-2010 academic year and those results will be presented at the conference associated with this document.

It should be noted that the maximum possible numerical value generated by the MCDM is 61 , while the minimum value is 6.1 . While the model could be used as a criterion referenced evaluation wherein any proposed project falling below a particular value would be rejected, that is not ultimately the anticipated application. Rather it will be utilized to evaluate proposed projects individually and in relation to previously evaluated projects. It is entirely conceivable that a proposed project would score relatively low on the scale, but would still receive authorization under special circumstances. In such a case, the model would be used to help evaluate the known risks of proceeding with the project. An example of a special case could include a project that generally scores low, but is enthusiastically proposed by a group of Cadets and supporting faculty with particularly high potential for personal and professional growth. Evaluation using the MCDM and the ultimate decision relative to authorization rests with the DC\&ME independent study coordinator. 
Table 3 - Pre- and Post-Performance Evaluation using the Multi-Criteria Decision Model

\begin{tabular}{|c|c|c|c|c|c|c|}
\hline Project & Description & $\begin{array}{l}\text { Pre- } \\
\text { Performance } \\
\text { Rank } \\
\end{array}$ & $\begin{array}{l}\text { Post- } \\
\text { Performance } \\
\text { Rank } \\
\end{array}$ & $\begin{array}{l}\text { Pre- } \\
\text { Performance } \\
\text { Evaluation } \\
\end{array}$ & $\begin{array}{l}\text { Post- } \\
\text { Performance } \\
\text { Evaluation }\end{array}$ & $\begin{array}{c}\% \\
\text { Difference }\end{array}$ \\
\hline Steel Bridge & $\begin{array}{l}\text { National competition sponsored by the American } \\
\text { Institute of Stcel Construction and the Amcrican } \\
\text { Socicty of Civil Engincers. }\end{array}$ & 2 & 5 & 36.2 & 39.9 & 9.2 \\
\hline Timber Bridge & $\begin{array}{l}\text { National competition sponsored by the Forest } \\
\text { Product Society and the American Society of } \\
\text { Civil Engineers. }\end{array}$ & 5 & 3 & 30.5 & 41.5 & 26.4 \\
\hline Concrete Canoc & $\begin{array}{l}\text { National competition sponsored by the American } \\
\text { Society of Civil Engineers. }\end{array}$ & 3 & 4 & 35.5 & 41.2 & 13.7 \\
\hline Agricultural Building Design & $\begin{array}{l}\text { Complete design and siting of turkey processing } \\
\text { facility for a one-time project sponsor. }\end{array}$ & 11 & 11 & 18.6 & 19.0 & 1.8 \\
\hline Bannerman Island Irrigation & $\begin{array}{l}\text { Design and construction of a large scale garden } \\
\text { irrigation system for a local privite trust } \\
\text { organization. }\end{array}$ & 10 & 6 & 27.8 & 38.3 & 27.4 \\
\hline High Performance Concrete & $\begin{array}{l}\text { Design and evaluation of multiple high-strength } \\
\text { concrete products as part of an externally funded } \\
\text { research program. }\end{array}$ & 1 & 1 & 40.8 & 53.0 & 23.0 \\
\hline $\begin{array}{l}\text { Security Fng. \& Protective } \\
\text { Design }\end{array}$ & $\begin{array}{l}\text { Design of a future course focusing on security } \\
\text { engineering and protective design. }\end{array}$ & 9 & 2 & 27.9 & 49.7 & 43.8 \\
\hline USMA Sustainable Housing & $\begin{array}{l}\text { Design and economic evaluation of a sustainable } \\
\text { log home for use by the academic institution. }\end{array}$ & 8 & 10 & 28.7 & 30.1 & 4.5 \\
\hline Transportation Course & $\begin{array}{l}\text { Design of a future course focusing on an } \\
\text { introduction to transportation cngincering. }\end{array}$ & 6 & 9 & 30.3 & 32.4 & 6.5 \\
\hline Cross-Fit Facility & $\begin{array}{l}\text { Design, analyze, and fabrication of equipment, as } \\
\text { well as design and oversight of reconfiguration of } \\
\text { workout room for the academic institution. }\end{array}$ & 4 & 8 & 35.0 & 34.1 & 2.6 \\
\hline $\begin{array}{l}\text { Mahan Hall Loading Dock } \\
\text { Retrofit }\end{array}$ & $\begin{array}{l}\text { Design and preparation of a cost estimate for } \\
\text { construction of a loading dock retrofit for the } \\
\text { Department. }\end{array}$ & 7 & 7 & 29.9 & 36.6 & 18.2 \\
\hline Project & Description & $\begin{array}{l}\text { Pre- } \\
\text { Performance } \\
\text { Rank }\end{array}$ & $\begin{array}{l}\text { Post- } \\
\text { Performance } \\
\text { Rank }\end{array}$ & $\begin{array}{l}\text { Pre- } \\
\text { Performance } \\
\text { Evaluation }\end{array}$ & $\begin{array}{l}\text { Post- } \\
\text { Performance } \\
\text { Evaluation }\end{array}$ & $\begin{array}{c}\% \\
\text { Difference }\end{array}$ \\
\hline Steel Bridge & $\begin{array}{l}\text { National competition sponsored by the American } \\
\text { Institute of Steel Construction and the American } \\
\text { Society of Civil Engineers. }\end{array}$ & 2 & \multirow{8}{*}{ 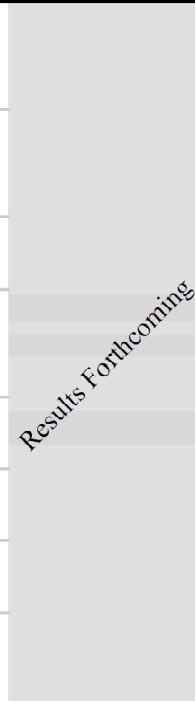 } & 36.2 & \multirow{8}{*}{$\mathrm{e}^{\mathrm{S}^{\circ}}$} & \\
\hline Timber Bridge & $\begin{array}{l}\text { National competition sponsored by the Forcst } \\
\text { Product Society and the American Society of } \\
\text { Civil Engineers. }\end{array}$ & 5 & & 30.5 & & \\
\hline Concrete Canoe & $\begin{array}{l}\text { National competition sponsored by the American } \\
\text { Society of Civil Engineers. }\end{array}$ & 3 & & 35.5 & & \\
\hline Alternative Energy & $\begin{array}{l}\text { Research on the feasibility of application of } \\
\text { alternative energy sources for a local application. }\end{array}$ & 4 & & 35.4 & & \\
\hline Wind Challenge & $\begin{array}{l}\text { Design and construction of a small-scale wind } \\
\text { turbine without a particular project sponsor. }\end{array}$ & 7 & & 27.8 & & \\
\hline $\begin{array}{l}\text { Parking Lot Walkway Design } \\
\text { and Reconstruction }\end{array}$ & $\begin{array}{l}\text { Design and reconstruction of a walkway for a } \\
\text { facility at the academic institution. }\end{array}$ & 6 & & 28.2 & & \\
\hline Aerial Tram & $\begin{array}{l}\text { Development of a creative transportation solution } \\
\text { for a one-time client. }\end{array}$ & 8 & & 25.5 & & \\
\hline $\begin{array}{l}\text { Statuc of Libcrty Rescuc } \\
\text { System }\end{array}$ & $\begin{array}{l}\text { Design and oversight of protype construction for a } \\
\text { rescure system for the National Parks Service. }\end{array}$ & 1 & & 40.9 & & \\
\hline
\end{tabular}


When the pre-performance and post-performance MCDM results are compared for individual projects, several interesting observations can be made. First, with the exception of only one project, all of the projects generated higher post-performance values than the pre-performance values. This might suggest that the model is dependent upon the amount of information available for consideration. The pre-performance values were generated using limited information, which is realistic of the assessment that is typically completed when considering proposed projects. While nearly half of the pre- and post-performance values differed by less than $10 \%$, several of the projects have significant differences in the pre- and post- values. Looking at the pre-performance and post-performance rankings, in general projects that were predicted to be successful were also ranked as having been successful upon completion. While the model appears to provide a general evaluation of the merit of potential projects, it is not a perfect predictor of project success. Nor was it intended to perform as such. It is anticipated that the true value of the model will be in its future evaluation of proposed independent study projects in relation to a dataset of prior highly successful and less successful projects. That dataset currently includes the 11 projects completed during the 2008-2009 academic year and will include the addition of 8 more projects by the end of the 2009-2010 academic year.

\section{Conclusions}

The model developed and evaluated during this study represents a measured approach to evaluating potential civil engineering independent study projects. The authors utilized well studied decision making model strategies and selected an appropriate model based on specific conditions. Extensive consideration was given to the applied list of criteria, their respective weighting, and scale values. The weighting was evaluated using Analytical Hierarchy Process to ensure that the applied values were unbiased.

The model has shown particular merit in evaluating proposed independent study projects. Continued growth of the pre-performance and post-performance dataset will provide a useful comparison during the future application of the model.

It is anticipated that the D-C\&ME at the United States Military Academy is not alone in their desire and need to make carefully measured decisions and curriculum changes during this time of fiscal limitations. Accordingly, the authors anticipate that the process detailed in this document and perhaps an adapted model to meet specific needs will be of interest to other program administrators facing similar multiple-criteria decisions.

\section{References}

1. Hoskin, J. R. and Welch, R. W., "Scope Management for Independent Study Projects," Proceedings of the 2003 American Society for Engineering Education Annual Conference \& Exposition, American Society for Engineering Education, Nashville, Tennessee, 2003.

2. Welch, R. W. and Estes, A. C.., "Client-Based Projects for Every Senior - A Mark of Excellence for Any Program," Proceedings of the 2003 American Society for Engineering Education Annual Conference \& Exposition, American Society for Engineering Education, Nashville, Tennessee, 2003. 
3. Welch, R. W. and Evans, M. D., "Undergraduate Independent Study Research Projects," Proceedings of the 2004 American Society for Engineering Education Annual Conference \& Exposition, American Society for Engineering Education, Salt Lake City, Utah, 2004.

4. Blumenfeld, P. C, Soloway, E., Marx, R. W., Krajcik, J. S., Guzdial, M., and Palincsar, A., "Motivating ProjectBased Learning: Sustaining the Doing, Supporting the Learning," Educational Psychologist, Lawrence Erlbaum Associates, Inc., Hillsdale, New Jersey, 26(3 \& 4), 369-398, 1991.

5. Gehringer, E. F., "Using Independent-Study Projects in Your Research, Teaching and Service Program," Proceedings of the 2007 American Society for Engineering Education Annual Conference \& Exposition, American Society for Engineering Education, Honolulu, Hawaii, 2007.

6. McKeachie, W. J., McKeachie's Teaching Tips, Houghton Mifflin Company, Boston, Massachusetts, 2002.

7. Michaelsen, L. K., "Team Learning: Making a Case for the Small-Group Option," in Handbook of College Teaching: Theory and Applications, Prichard, K. W. and Sawyer, R. M. L. editors, Greenwood Press, Westport, Connecticut, 1994.

8. Sanford-Bernhardt, K. L. and Roth, M. J. S.., "Undergraduate Research: The Lafayette Experience," Proceedings of the 2004 American Society for Engineering Education Annual Conference \& Exposition, American Society for Engineering Education, Salt Lake City, Utah, 2004.

9. Zimmermann, H. -J., Fuzzy Set Theory and Its Applications, Kluwer Academic Publishers, Amsterdam, The Netherlands, 1996.

10. Chen, S. J. and Hwang, C. L., "Fuzzy Multiple Attribute Decision Making: Methods and Applications," Lecture Notes in Economics and Mathematical Systems, No. 375, Sringer-Verlag, Berlin, Germany, 1991.

11. Lootsma, F. A., Fuzzy Logic for Planning and Decision Making, Kluwer Academic Publishers, Dordrecht, The Netherlands, 1997.

12. Trintaphyllou, E., Multi-Criteria Decision Making Methods: A Comparative Study, Kluwer Academic Publishers, Dordrecht, The Netherlands, 2000.

13. Yu, P. -L., Multiple-Criteria Decision Making, Plenum Press, New York, New York, 1985.

14. Department of Civil \& Mechanical Engineering, "2010 Strategic Plan,” United States Military Academy, internal document, working draft, November 2009.

15. Ragsdale, C. T., Spreadsheet Modeling \& Decision Analysis, Thomson, Mason, Ohio, 2004.

16. Department of Civil \& Mechanical Engineering, "CE489 Planning and Faculty Coordination," United States Military Academy, internal memorandum, September 2009. 